\title{
Tolerance of Hooker's Evening Primrose Transplants to Preemergence Herbicides
}

\author{
Amber N. Bates ${ }^{1}$, Gerald M. Henry ${ }^{2,3}$, and Cynthia B. McKenney ${ }^{1}$
}

AdDitional INDEX wORDs. biomass, Oenothera elata, ornamentals, phytotoxicity, plant growth index

SUMMARY. No research has investigated the phytotoxic response of hooker's evening primrose (Oenothera elata) plug transplants to preemergence herbicides. Varied phytotoxic responses of common evening primrose (Oenothera biennis) to preemergence herbicides suggest that options may exist for the safe control of weeds present within hooker's evening primrose when grown as an agronomic field crop. Enhanced weed control during early establishment may reduce competition for water and nutrients as well as increase seed yield and oil content. Therefore, the objective of this research was to determine the phytotoxic effect of preemergence herbicides on hooker's evening primrose plug transplants grown in the greenhouse. Research was conducted in 2010 and 2011 at the Plant and Soil Science greenhouse complex at Texas Tech University in Lubbock, TX. Herbicide treatments were applied on 13 July 2010 and 5 Apr. 2011 and consisted of oxadiazon at $3 \mathrm{lb} /$ acre, isoxaben at $0.5 \mathrm{lb} / \mathrm{acre}$, oryzalin at $2 \mathrm{lb} /$ acre, prodiamine at $1.5 \mathrm{lb} / \mathrm{acre}$, dithiopyr at $0.5 \mathrm{lb} /$ acre, s-metolachlor at $1.8 \mathrm{lb} / \mathrm{acre}$, pendimethalin at $0.6 \mathrm{lb} / \mathrm{acre}$, and isoxaben + trifluralin at $2.5 \mathrm{lb} /$ acre. One 4 -month-old hooker's evening primrose plug ( 2 inches wide) was transplanted into each pot (3 gal) 2 days after treatment (DAT). Dithiopyr and s-metolachlor treatments exhibited similar lack of phytotoxicity as the untreated control 7 DAT. Phytotoxicity $\geq 13 \%$ was observed for trifluralin + isoxaben, pendimethalin, prodiamine, oryzalin, isoxaben, and oxadiazon 7 DAT, with the highest level of phytotoxicity (24\%) exhibited by trifluralin + isoxaben treatments. Hooker's evening primrose phytotoxicity decreased (plants grew out of the damage) for all treatments except trifluralin + isoxaben, pendimethalin, and oryzalin 28 DAT. Oryzalin (16\%) and trifluralin + isoxaben $(60 \%)$ were the only two treatments that did not exhibit similar phytotoxicity to the untreated control 28 DAT. There were no significant differences in aboveground or belowground biomass nor plant growth index (PGI) of any of the treatments when compared with the untreated control 28 DAT. Based upon the results of this trial, pendimethalin, prodiamine, dithiopyr, s-metolachlor, oryzalin, isoxaben, and oxadiazon may be used for preemergence weed control in hooker's evening primrose without causing excessive phytotoxicity $(>20 \%)$, potential yield loss, or both. Trifluralin + isoxaben treatments exhibited $60 \%$ hooker's evening primrose phytotoxicity $28 \mathrm{DAT}$, which resulted in too low of an initial plant stand to warrant use.

$\mathrm{H}$ ooker's evening primrose is a biennial to short-lived perennial native to areas as far north as Oregon, south as Panama, east as Texas, and west as coastal California (Dietrich et al., 1997). Plants are often found in full sun along streams and rocky slopes as well as in meadows and disturbed areas (Arnold, 2008; Dietrich et al., 1997). Hooker's evening primrose shoots (1.5 to $8 \mathrm{ft}$ tall) emerge from

The authors acknowledge the cooperation of Tyler Cooper, Leslie Beck, A.J. Hephner, Vikram Baliga, Kaylee Decker, and Daniel Cunningham for their technical assistance in this project.

${ }^{1}$ Department of Plant and Soil Science, Texas Tech University, Box 42122, Lubbock, TX 79409

${ }^{2}$ Department of Crop and Soil Sciences, University of Georgia, 3111 Miller Plant Sciences Building, Athens, GA 30602

${ }^{3}$ Corresponding author. E-mail: gmhenry@uga.edu. the center of a basal rosette at about the 20- to 50-leaf stage (Dietrich et al., 1997; Harte, 1994). Leaves are dull green to gray-green with bluntly dentate or subentire margins (Dietrich et al., 1997). Showy yellow flowers (1.2 to 1.4 inches wide) usually only occur once at sunrise or sunset during periods of long days and short nights (Correll and Johnston, 1970;
Dietrich et al., 1997; Harte, 1994). Flowers are pollinated by hawk moths (family Sphingidae) and give rise to seed capsules measuring 0.8 to 2.6 inches long (Dietrich et al., 1997). Each capsule splits in four places and may contain up to 500 seeds (Harte, 1994).

Drought tolerance and floral attributes of hooker's evening primrose have led to its use as an ornamental plant in xeriscapes throughout arid and semiarid regions of the United States (Arnold, 2008). High levels of $\gamma$-linolenic acid, an omega-3 fatty acid essential for human metabolism, present in seed oil has further increased interest in the cultivation of this plant as an agronomic crop (Balch et al., 2003). However, because of poor field germination, hooker's evening primrose must first be propagated in the greenhouse and transplanted into the field following maturation to the rosette stage (Murphy et al., 1999).

The presence of weeds in agricultural fields often increases the time and costs of crop production as well as reduces crop yields and quality (Anderson, 1996). Bridges (1992) estimated that the average annual monetary loss because of weed competition in 46 U.S. grown crops was $\$ 4$.1 billion in 1991. Losses are directly proportionate to the amount of light, water, and nutrients that weeds intercept from the agronomic crops they infest (Buchanan and Burns, 1970). The critical weed free period for many crops exists during early establishment. The critical weed free period for sorghum (Sorghum bicolor), beet (Beta vulgaris), and field bean (Phaseolus vulgaris) to prevent yield loss is 4,9 to 12 , and 5 to 7 weeks, respectively (Burnside and Wicks, 1967; Dawson, 1964, 1965). Early critical weed-freeperiods and phytotoxicity concerns associated with many postemergence herbicides make preemergence herbicide applications even more important.

\begin{tabular}{llll}
\hline $\begin{array}{l}\text { Units } \\
\text { To convert U.S. to SI, } \\
\text { multiply by }\end{array}$ & U.S. unit & SI unit & $\begin{array}{l}\text { To convert SI to U.S., } \\
\text { multiply by }\end{array}$ \\
\hline 0.3048 & $\mathrm{ft}$ & $\mathrm{m}$ & 3.2808 \\
3.7854 & gal & $\mathrm{L}$ & 0.2642 \\
9.3540 & gal/acre & $\mathrm{L} \cdot \mathrm{ha}^{-1}$ & 0.1069 \\
2.54 & inch $(\mathrm{es})$ & $\mathrm{cm}$ & 0.3937 \\
1.1209 & $\mathrm{lb} / \mathrm{acre}$ & $\mathrm{kg} \cdot \mathrm{ha}^{-1}$ & 0.8922 \\
28.3495 & $\mathrm{oz}$ & $\mathrm{g}$ & 0.0353 \\
6.8948 & $\mathrm{psi}$ & $\mathrm{kPa}$ & 0.1450 \\
$\left({ }^{\circ} \mathrm{F}-32\right) \div 1.8$ & ${ }^{\circ} \mathrm{F}$ & ${ }^{\circ} \mathrm{C}$ & $\left({ }^{\circ} \mathrm{C} \times 1.8\right)+32$ \\
& & &
\end{tabular}


Few research trials have focused on the phytotoxic effect of preemergence herbicides on evening primrose species. Richardson and West (1986) observed no reduction in common evening primrose fresh shoot weight grown from seed $42 \mathrm{DAT}$ in response to isoxaben $\left(0.075 \mathrm{~kg} \cdot \mathrm{ha}^{-1}\right)$ and trifluralin (1.0 and $\left.2.0 \mathrm{~kg} \cdot \mathrm{ha}^{-1}\right)$. However, applications of simazine $(0.25$ and $\left.0.5 \mathrm{~kg} \cdot \mathrm{ha}^{-1}\right)$, chlorsulfuron $(0.01$ and $0.02 \mathrm{~kg} \cdot \mathrm{ha}^{-1}$ ), and metsulfuron $\left(0.00375\right.$ and $\left.0.0075 \mathrm{~kg} \cdot \mathrm{ha}^{-1}\right)$ were lethal to common evening primrose at 42 DAT. Stringer et al. (1985) reported $91 \%$ to $100 \%$ survival of seeded common evening primrose at $68 \mathrm{DAT}$ in response to trifluralin $\left(0.8 \mathrm{~kg} \cdot \mathrm{ha}^{-1}\right)$, EPTC $\left(2.0 \mathrm{~kg} \cdot \mathrm{ha}^{-1}\right)$, propachlor $\left(4.0 \mathrm{~kg} \cdot \mathrm{ha}^{-1}\right)$, and linuron $\left(0.25 \mathrm{~kg} \cdot \mathrm{ha}^{-1}\right)$. However, when applied at a higher rate, linuron $\left(1.0 \mathrm{~kg} \cdot \mathrm{ha}^{-1}\right)$ and lenacil $\left(0.5\right.$ and $\left.2.0 \mathrm{~kg} \cdot \mathrm{ha}^{-1}\right)$ reduced common evening primrose survival below $9 \%$ at 68 DAT.

No research has investigated the phytotoxic response of hooker's evening primrose plug transplants to preemergence herbicides. Varied phytotoxic responses of common evening primrose to preemergence herbicides suggest that options may exist for the safe control of weeds present within hooker's evening primrose when grown as an agronomic field crop. Enhanced weed control during early establishment may reduce competition for water and nutrients as well as increase seed yield and oil content. Therefore, the objective of this research was to determine the phytotoxic effect of preemergence herbicides on hooker's evening primrose plug transplants grown in the greenhouse.

\section{Materials and methods}

Experiments were conducted in 2010 and 2011 at the Plant and Soil Science greenhouse complex at Texas Tech University in Lubbock, TX. Pots (3 gal) were filled with a Brownfield sandy clay loam (Loamy, mixed, superactive, thermic Arenic Aridic Paleustalfs) with a $\mathrm{pH}$ of 8.1 and organic matter content of $1.4 \%$. The trial was arranged in a randomized complete block design with five replications. Herbicide treatments were applied on 13 July 2010 and 5 Apr. 2011 and consisted of oxadiazon (Ronstar FLO; Bayer Environmental Science, Research Triangle Park, NC) at $3.0 \mathrm{lb} / \mathrm{acre}$, isoxaben (Gallery;
Dow AgroSciences, Indianapolis, IN) at $0.5 \mathrm{lb} / \mathrm{acre}$, oryzalin (Surflan; United Phosphorous, King of Prussia, PA) at $2.0 \mathrm{lb} /$ acre, prodiamine (Barricade; Syngenta Professional Products, Greensboro, NC) at 1.5 $\mathrm{lb} / \mathrm{acre}$, dithiopyr (Dimension, Dow AgroSciences) at $0.5 \mathrm{lb} / \mathrm{acre}$, s-metolachlor (Pennant Magnum, Syngenta Professional Products) at $1.8 \mathrm{lb} /$ acre, pendimethalin (Pendulum; BASF Specialty Products, Research Triangle Park, NC) at 0.6 $\mathrm{lb} / \mathrm{acre}$, and isoxaben + trifluralin (Snapshot, Dow AgroSciences) at $2.5 \mathrm{lb} / \mathrm{acre}$. An untreated control was included for comparison. Preemergence herbicide application rates were chosen based on label recommendations for similar crops and transplant size. Treatments were applied using a carbon dioxidepressurized backpack sprayer equipped with 8004VS nozzles (extended range flat spray tips; TeeJet Technologies, Wheaton, IL) calibrated to deliver $40 \mathrm{gal} /$ acre at $32 \mathrm{psi}$. One 4-month-old hooker's evening primrose plug ( $\approx 2$ inches wide) was transplanted into each pot 2 DAT. A single plug was used per pot to avoid negative impacts from plant competition and/or root distribution within the pot. Slow release fertilizer (14N6.1P-11.6K, Osmocote; Scotts, Marysville, $\mathrm{OH}$ ) was applied at the time of transplant at a rate of $43 \mathrm{lb} /$ acre nitrogen. Greenhouse temperatures were maintained at $93 / 79^{\circ} \mathrm{F}$ (day/ night) with average midday (1200 and $1300 \mathrm{HR}$ ) solar radiation ranging from 636 to $754 \mu \mathrm{mol} \cdot \mathrm{m}^{-2} \cdot \mathrm{s}^{-1}$. Irrigation was supplied through an overhead irrigation system calibrated to deliver $\approx 1.5$ inches of water per week.

Data collected included hooker's evening primrose phytotoxicity, biomass measurements, and PGI. Phytotoxicity was evaluated 7 and 28 DAT on a scale of 0 (no hooker's evening primrose phytotoxicity) to $100 \%$ (complete plant death). Plants exhibiting $25 \%$ phytotoxicity were slightly stunted and had minor leaf tip burn and leaf chlorosis, while plants exhibiting 50\% phytotoxicity were stunted, chlorotic, slightly necrotic, and exhibited epinasty/stem collapse. Plants were destructively harvested 28 DAT in both experiments. Plants were divided into shoots and roots, dried, and weighed to determine above- and belowground biomass (grams). Plant height and two plant widths (perpendicular to each other) were recorded 28 DAT to calculate PGI. PGI was calculated by averaging the plant height and two plant widths according to Behandary et al. (1997).

Hooker's evening primrose phytotoxicity, biomass measurements, and PGI measurements were arcsine square-root transformed to stabilize variance (Ahrens et al., 1990) before being subjected to analysis of variance in SAS (version 9.3; SAS Institute, Cary, NC), with main effects and all possible interactions tested using the appropriate expected mean square values described by McIntosh (1983). Interpretations were not different from nontransformed data; therefore, nontransformed means are presented for clarity. No significant run-bytreatment interactions were detected so data were combined. All data were subjected to analysis of variance in SAS using the appropriate expected mean square values described by McIntosh (1983). Treatment means were separated using Fisher's protected least significant difference test at $\alpha=0.05$.

\section{Results and discussion}

Dithiopyr and s-metolachlor treatments exhibited similar lack of phytotoxicity as the untreated control 7 DAT (Table 1). Derr (1993) observed similar phytotoxicity $(0 \%$ to 12\%) 2 weeks after treatment (WAT) to transplants of lanceleaf coreopsis (Coreopsis lanceolata), ox-eye daisy (Chrysanthemum leucantheum), blanket flower (Gaillardia aristata), and purple coneflower (Echinacea purpurea) in response to metolachlor at 4.5 and $9.0 \mathrm{~kg} \cdot \mathrm{ha}^{-1}$. Phytotoxicity $\geq 13 \%$ was observed for trifluralin + isoxaben, pendimethalin, prodiamine, oryzalin, isoxaben, and oxadiazon 7 DAT, with the highest level of phytotoxicity $(24 \%)$ exhibited by trifluralin + isoxaben treatments.

Hooker's evening primrose phytotoxicity decreased (plants grew out of the initial damage) for all treatments except trifluralin + isoxaben, pendimethalin, and oryzalin 28 DAT (Table 1). Oryzalin $(16 \%)$ and trifluralin + isoxaben $(60 \%)$ were the only two treatments that did not exhibit similar phytotoxicity to the untreated control 28 DAT. Similar phytotoxicity (2.1 to 2.6 on a scale of 
Table 1. Response of hooker's evening primrose transplants to preemergence herbicides in the greenhouse in Lubbock, TX. Data were pooled across experimental runs.

\begin{tabular}{|c|c|c|c|c|c|c|}
\hline \multirow[b]{2}{*}{ Treatment } & \multirow[b]{2}{*}{ Rate $(1 \mathrm{~b} / \text { acre })^{\mathrm{z}}$} & $7 \mathrm{DAT}^{\mathrm{y}}$ & $28 \mathrm{DAT}$ & Aboveground & Belowground & \multirow[b]{2}{*}{ PGI $^{w}$} \\
\hline & & \multicolumn{2}{|c|}{ Phytotoxicity $(\%)^{x}$} & \multicolumn{2}{|c|}{ Biomass $(\mathrm{g})^{\mathrm{z}}$} & \\
\hline Untreated control & - & 0 & 0 & 0.53 & 0.29 & 10.9 \\
\hline Pendimethalin & 0.6 & 13 & 13 & 0.58 & 0.17 & 10.6 \\
\hline Prodiamine & 1.5 & 15 & 6 & 0.57 & 0.25 & 11.1 \\
\hline Dithiopyr & 0.5 & 8 & 4 & 0.63 & 0.23 & 12.5 \\
\hline Isoxaben & 0.5 & 13 & 7 & 0.54 & 0.21 & 11.7 \\
\hline Oxadiazon & 3.0 & 15 & 10 & 0.39 & 0.21 & 8.1 \\
\hline $\operatorname{LSD}_{0.05}{ }^{\mathrm{v}}$ & & 12 & 15 & 0.34 & 0.15 & 5.4 \\
\hline
\end{tabular}

${ }^{\mathrm{z}} \mathrm{l} \mathrm{lb} / \mathrm{acre}=1.1209 \mathrm{~kg} \cdot \mathrm{ha}^{-1}, \mathrm{l} \mathrm{g}=0.0353 \mathrm{oz}$.

'Days after treatment.

${ }^{x}$ Phytotoxicity was evaluated on a scale of $0 \%$ (no hooker's evening primrose phytotoxicity) to $100 \%$ (complete plant death). Plants exhibiting $25 \%$ phytotoxicity were slightly stunted and had minor leaf tip burn and leaf chlorosis, while plants exhibiting $50 \%$ phytotoxicity were stunted, chlorotic, slightly necrotic, and exhibited epinasty/stem collapse. wPlant growth index was calculated by averaging the plant height and two plant widths according to Behandary et al. (1997).

"Fisher's protected least significant difference at $P \leq 0.05$.

$1=$ no injury to 5 = dead plant) was observed on 'Vodka' begonia (Begonia semperflorens-cultorum) and 'Fireball' salvia (Salvia splendens) 30 DAT in response to trifluralin + isoxaben at $3.4 \mathrm{~kg} \cdot \mathrm{ha}^{-1}$ (Thetford et al., 1995). Pendimethalin, prodiamine, dithiopyr, s-metolachlor, isoxaben, and oxadiazon all exhibited $\leq 13 \%$ hooker's evening primrose phytotoxicity 28 DAT. Gilreath et al. (2008) observed similar phytotoxicity of four-true-leaf leek ( $\mathrm{Al}$ lium porrum) transplants to pendimethalin $(11 \%)$ at $1.1 \mathrm{~kg} \cdot \mathrm{ha}^{-1}$, but greater phytotoxicity in response to metolachlor $(38 \%)$ at $2.3 \mathrm{~kg} \cdot \mathrm{ha}^{-1}$ and prodiamine $(18 \%)$ at $1.7 \mathrm{~kg} \cdot \mathrm{ha}^{-1} 4$ weeks after planting.

There were no significant differences in above- or belowground biomass of any of the treatments when compared with the untreated control 28 DAT (Table 1). Neal and Senesac (1990) reported no reduction in aboveground biomass of stock plant division transplants of 'Albomarginata' plantain lily (Hosta lancifolia) $92 \mathrm{~d}$ after initial treatment in response to sequential applications of isoxaben $\left(1.1 \mathrm{~kg} \cdot \mathrm{ha}^{-1}\right)$, oryzalin $\left(4.5 \mathrm{~kg} \cdot \mathrm{ha}^{-1}\right)$, and trifluralin + isoxaben $\left(4.24 \mathrm{~kg} \cdot \mathrm{ha}^{-1}\right)$. Derr and Salihu (1996) observed similar belowground biomass results ( 0.4 to $0.9 \mathrm{~g})$ on 'Edward Goucher' abelia (Abelia $\times$ grandiflora $\times$ A. Schumannii) 5 weeks after sequential application of oxadiazon $\left(4.48 \mathrm{~kg} \cdot \mathrm{ha}^{-1}\right)$, isoxaben $\left(1.12 \mathrm{~kg} \cdot \mathrm{ha}^{-1}\right)$, and oryzalin (4.48 $\mathrm{kg} \cdot \mathrm{ha}^{-1}$ ) compared with the untreated control ( $1.4 \mathrm{~g})$. No significant differences in PGI were detected for any of the treatments when compared with the untreated control 28 DAT (Table 1).

Methods employed in this research may have increased the incidence of hooker's evening primrose phytotoxicity compared with trials conducted in the field. Plants grown under greenhouse conditions are often more susceptible to herbicides, and therefore exhibit higher levels of phytotoxicity. Coffman and Gentner (1980) reported $68 \%$ and $30 \%$ italian ryegrass (Lolium multiflorum) phytotoxicity 1 WAT in response to trifluralin at $1.1 \mathrm{~kg} \cdot \mathrm{ha}^{-1}$ when applied in the field and greenhouse, respectively. Transplant size may also have an effect on herbicide phytotoxicity. Hooker's evening primrose transplants used in our research were 2 inches wide when herbicides were applied. Larger transplants may have reduced herbicide phytotoxicity. Derr and Salihu (1996) reported that a decrease in efficacy of several preemergence herbicides on redtip photinia (Photinia $\times$ fraserii), 'Tradition' azalea (Rhododendron obtusum), abelia (Abelia grandiflora $\times$ A. Schumannii), and 'Helleri' japanese holly (Ilex crenata) may have been caused by an increase in plant size. Miller et al. (2003) observed greater yields $\left(34 \mathrm{~kg} \cdot \mathrm{ha}^{-1}\right)$ of large transplant (five to six true leaves) cabbage (Brassica oleracea var. capitata) compared with small transplants (four to five true leaves) $\left(5 \mathrm{~kg} \cdot \mathrm{ha}^{-1}\right)$ in response to preemergence applications of pendimethalin at $1.7 \mathrm{~kg} \cdot \mathrm{ha}^{-1}$. Preemergence herbicide trials conducted in the greenhouse are often criticized for potential leaching and subsequent reduced soil residual activity. Field soil used in our research was excavated from the Quaker Research farm in Lubbock, TX, and contained a natural population of weed seed. Although untreated plant pots were hand-weeded to avoid negative impacts from weed competition, minimal to no weed pressure was observed in any treated pot (data not shown). Therefore, it can be assumed that herbicide leaching was held to a minimum.

Based upon the results of this trial, pendimethalin, prodiamine, dithiopyr, s-metolachlor, oryzalin, isoxaben, and oxadiazon may be used for preemergence weed control in hooker's evening primrose without causing excessive phytotoxicity $(>20 \%)$ and potential yield loss. Trifluralin + isoxaben treatments exhibited 60\% hooker's evening primrose phytotoxicity $28 \mathrm{DAT}$, which resulted in too low of an initial plant stand to warrant use.

\section{Literature cited}

Ahrens, W.H., D.J. Cox, and G. Budhwar. 1990. Use of the arcsine and square root transformations for subjectively determined percentage data. Weed Sci. 38: $452-458$

Anderson, W.P. 1996. Weed science: Principles and applications. 3rd ed. Waveland Press, Long Grove, IL.

Arnold, M. 2008. Landscape plants for Texas and environs. 3rd ed. Stipes Publishing, Champaign, IL.

Balch, S.A., C.B. McKenney, and D.L. Auld. 2003. Evaluation of gamma-linolenic acid composition of evening primrose 
(Oenothera) species native to Texas. HortScience 38:595-598.

Behandary, R.M., T. Whitwell, and J. Briggs. 1997. Growth of containerized landscape plants is influenced by herbicide residues in irrigation water. Weed Technol. 11: 793-797.

Bridges, D.C. 1992. Crop losses due to weeds in the United States. Weed Sci. Soc. Amer., Champaign, IL.

Buchanan, G.A. and E.R. Burns. 1970. Influence of weed competition on cotton. Weed Sci. 18:149-154.

Burnside, O.C. and G.A. Wicks. 1967. The effect of weed removal treatments on sorghum growth. Weeds 15:204-207.

Coffman, C.B. and W.A. Gentner. 1980. Persistence of several controlled release formulations of trifluralin in greenhouse and field. Weed Sci. 28:21-23.

Correll, D.S. and M.C. Johnston. 1970. Manual of the vascular plants of Texas. Texas Res. Foundation, Renner, TX.

Dawson, J.H. 1964. Competition between irrigated field beans and annual weeds. Weeds 12:206-208.
Dawson, J.H. 1965. Competition between irrigated sugar beets and annual weeds. Weeds 13:245-249.

Derr, J. 1993. Wildflower tolerance to metolachlor and metolachlor combined with other broadleaf herbicides. HortScience 28:1023-1026.

Derr, J. and S. Salihu. 1996. Preemergence herbicide effects on nursery crop root and shoot growth. J. Environ. Hort. 14:210213.

Dietrich, W., P.H. Raven, and W.L. Wagner. 1997. Systematics of Oenothera section Oenothera subsection Oenothera (Onagraceae). Amer. Soc. Plant Taxonomists, Laramie, WY.

Gilreath, J.P., B.M. Santos, P.R. Gilreath, and D.N. Maynard. 2008. Efficacy of early post-transplant herbicides in leeks (Allium porrum L.). Crop Protection 27:847-850.

Harte, C. 1994. Oenothera: Contributions of a plant to biology. SpringerVerlag. Berlin, Germany.

McIntosh, M.S. 1983. Analysis of combined experiments. Agron. J. 75:153-155.
Miller, A.J., R.R. Bellinder, B. Xu, B.J. Rauch, M.C. Goffinet, and M.J.C. Welser. 2003. Cabbage (Brassica oleracea) response to pendimethalin applied posttransplant. Weed Technol. 17:256-260.

Murphy, C.L., N.W. Hopper, C.B. McKenney, and D.L. Auld. 1999. 263 selected seed treatments to enhance germination of oil-bearing Oenothera species. HortScience 34(3):487. (abstr.).

Neal, J.C. and A.F. Senesac. 1990. Preemergent weed control in container and field grown woody nursery crops with gallery. J. Environ. Hort. 8:103-107.

Richardson, W.G. and T.M. West. 1986. Tolerance of evening primrose (Oenothera biennis) and borage (Borago officinalis) to pre-emergence herbicides. Ann. Appl. Biol. 108:138-139.

Stringer, D., W.G. Richardson, and C. Parker. 1985. Tolerance of Oenothera biennis to various herbicide treatments. Tests Agrochemicals Cultivars 6:124-125.

Thetford, M., C.H. Gilliam, and J.D. Williams. 1995. Granular preemergence applied herbicides influence annual bedding plant growth. J. Environ. Hort. 13:97-103. 